\title{
Aktivitas Antibakteri Campuran Ekstrak Kulit Batang Merkubung (Macaranga gigantea) dan Mangpurang (Macaranga triloba) Terhadap Enterococcus faecalis dan Escherichia coli
}

\section{Antibacterial Activity of Mixture of Wood Bark Extracts of Merkubung (Macaranga gigantea) and Mangpurang (Macaranga triloba) on Enterococcus faecalis and Escherichia coli}

\author{
Puput Sulastri*, Yeni Mariani, Fathul Yusro \\ Fakultas Kehutanan Universitas Tanjungpura Jalan Daya Nasional, \\ Pontianak 78124 \\ *E-mail: puputsula@gmail.com
}

(Article History: Received 28 April 2020; Revised 9 Mei 2020; Accepted 31 Mei 2020)

\begin{abstract}
ABSTRAK
Ramuan obat tradisional umumnya berasal dari satu jenis tanaman ataupun berasal dari campuran beberapa jenis tanaman. Campuran ekstrak tanaman merkubung (Macaranga gigantea) dan mangpurang (Macaranga triloba) berpotensi menghambat pertumbuhan bakteri Enterococcus faecalis dan Escherichia coli. Penelitian ini bertujuan untuk menganalisis aktivitas penghambatan pertumbuhan bakteri E. faecalis dan E. coli dari campuran ekstrak kulit kayu merkubung ( $M$. gigantea) dan mangpurang ( $M$. triloba). Penelitian ini menggunakan konsentrasi ekstrak $200 \mathrm{mg} / \mathrm{ml}$ yang dibuat dengan mencampurkan ekstrak merkubung dan mangpurang dalam satu ml larutan dengan beberapa tingkat perbandingan yaitu 200:0; 150:50; 100:100; 50:150 dan 0:200 (b/b). Campuran ekstrak etanol dari kulit batang merkubung dan mangpurang pada konsentrasi $200 \mathrm{mg} / \mathrm{ml}$ dengan perbandingan ekstrak 200:0; 150:50; 100;100 dan 50:150 memiliki aktivitas penghambatan pertumbuhan bakteri $E$. faecalis dengan zona hambatan sebesar 1,4 mm;1,3 mm; 1,09 $\mathrm{mm}$ dan 0,94 $\mathrm{mm}$. Penghambatan pertumbuhan bakteri $E$. coli hanya dapat dilakukan oleh ekstrak merkubung (200:0) dengan zona hambat 1,08 mm.
\end{abstract}

Kata Kunci: campuran ekstrak; kulit kayu; Macaranga gigantea; Macaranga triloba; Enterococcus faecalis; Escherichia coli

\begin{abstract}
Traditional medicinal potion ingredients are generally derived from one species of plant or derived from a mixture of several species of plants. A mix of plant extracts of merkubung (Macaranga gigantea) and mangpurang (Macaranga triloba) has the potential to inhibit the growth of the bacteria Enterococcus faecalis and Escherichia coli. The research purposes were to analyze the activity of a mixture of extracts of the wood bark of merkubung (M. gigantea) and mangpurang (M. triloba) in inhibiting the growth of E. faecalis and E. coli bacteria. This study used an extract concentration of $200 \mathrm{mg} / \mathrm{ml}$. The concentration is made by mixing the extract of the merkubung and mangpurang in one $\mathrm{ml}$ of solution with several levels of comparison, namely 200: 0; 150: 50; 100: 100; 50: 150 and 0: $200(w / w)$. The mixture of ethanol extracts $(200 \mathrm{mg} / \mathrm{ml})$ from the wood bark of the merkubung and mangpurang with a ratio of 200: 0 extract; 150: 50; 100; 100 and 50: 150 can inhibit the growth of E. faecalis bacteria with inhibition zones of $1.4 \mathrm{~mm} ; 1.3 \mathrm{~mm} ; 1.09 \mathrm{~mm}$ and $0.94 \mathrm{~mm}$. The inhibition of the growth of E. coli bacteria can only be done by the extract of the wood bark (200: 0) with a $1.08 \mathrm{~mm}$ inhibition zone.
\end{abstract}

Keywords: $\quad$ extracts mixture; wood bark; Macaranga gigantea; Macaranga triloba; Enterococcus faecalis; Escherichia coli 


\section{PENDAHULUAN}

Pengobatan tradisional mempergunakan ramuan dari tumbuhan obat masih menjadi alternatif pilihan bagi masyarakat hingga saat ini, baik dipedesaan maupun perkotaan. Ramuan tersebut umumnya berasal dari satu jenis tanaman ataupun berasal dari campuran beberapa jenis tanaman (Yusro et al. 2019). Ramuan-ramuan yang dimanfaatkan oleh masyarakat telah banyak terbukti secara ilmiah dan umumnya dalam bentuk penggunaan tunggal atau tanpa campuran tanaman lain seperti hasil penelitian Pasaribu dan Setyawati (2011), Nuraini et al. (2015), Calsum et al. (2018), Nuriana et al. (2019), Priandi et al. (2019) dan Mariani et al. (2020).

Beberapa peneliti lain mencoba untuk membuktikan penggunaan tanaman dalam bentuk campuran atau kombinasi beberapa jenis tanaman seperti yang dilaporkan oleh Miksusanti et al. (2012) dengan ekstrak kulit buah manggis dan kayu secang terhadap aktivitas antioksidan, Wajdi et al. (2017) dengan campuran ekstrak biji kelor dan daun kersen terhadap Pseudomonas aeuroginosa dan Bacillus subtilis, dan hasil yang diperoleh lebih tinggi jika dibandingkan dengan penggunaan tunggal. Oleh karena itu, penelitian terkait campuran ekstrak penting untuk dilakukan dalam rangka meningkatkan aktivitas biologis dari beberapa jenis tanaman yang sudah diketahui aktivitasnya dalam bentuk penggunaan tunggal. Dua jenis tanaman yang sudah diketahui aktivitas biologisnya dalam bentuk tunggal adalah merkubung (Macaranga gigantea) dan mangpurang (Macaranga triloba) yang dapat menghambat pertumbuhan bakteri Enterococcus faecalis (Hidayat et al. 2019).

Merkubung dan mangpurang merupakan tanaman dari genus Macaranga dan penggunaan tradisionalnya adalah sebagai obat sariawan (Hidayat et al. 2019), diare dan infeksi yang disebabkan oleh bakteri (Amirta et al. 2017). Bakteri E. faecalis diketahui menyebabkan gangguan pada mulut khususnya pada saluran akar gigi (Djuanda et al. 2019) dan bakteri
Escherichia coli menyebabkan penyakit diare (Halim et al. 2017). Penelitian Hidayat et al. (2019) menunjukkan adanya aktivitas penghambatan pertumbuhan bakteri $E$. faecalis dari ekstrak kulit batang merkubung dan mangpurang pada konsentrasi 200 $\mathrm{mg} / \mathrm{ml}$ sebesar $5,25 \mathrm{~mm}$ dan $2,87 \mathrm{~mm}$, sedangkan pada bakteri $E$. coli belum diketahui. Aktivitas penghambatan pada konsentrasi $200 \mathrm{mg} / \mathrm{ml}$ tersebut masih tergolong rendah sehingga perlu untuk ditingkatkan, salah satunya dengan cara mencampurkan kedua jenis ekstrak tersebut. Namun belum ada data hingga saat ini yang menunjukkan apakah pencampuran kedua jenis ekstrak kulit batang merkubung dan mangpurang dapat meningkatkan aktivitas penghambatan pertumbuhan bakteri $E$. faecalis dan E. coli. Tujuan penelitian ini untuk menganalisis aktivitas penghambatan pertumbuhan bakteri E. faecalis dan E. coli dari campuran ekstrak kulit kayu merkubung dan mangpurang.

\section{METODE PENELITIAN}

Penelitian dilaksanakan pada dua laboratorium yaitu Teknologi Kayu Fakultas Kehutanan Universitas Tanjungpura dan Unit Laboratorium Kesehatan Pontianak. Peralatan yang dipergunakan yaitu laminar air flow, vortex, magnetic stirrer, mikropipet dan petri dish, sedangkan bahan-bahan yang dipergunakan berupa ekstrak etanol dari kulit batang merkubung ( $M$. gigantea) dan mangpurang (M. triloba), bakteri E. faecalis ATCC 29212 dan E. coli ATCC 25922, MHA (Mueller Hinton Agar), antibiotik tetracycline, dan larutan Mc. Farland 1.

Penelitian ini sebagai lanjutan dari penelitian Hidayat et al. (2019). Konsentrasi ekstrak yang digunakan adalah $200 \mathrm{mg} / \mathrm{ml}$. Konsentrasi tersebut dibuat dengan mencampurkan ekstrak merkubung dan mangpurang dalam satu ml larutan dengan beberapa tingkat perbandingan yaitu 200:0; 150:50; 100:100; 50:150 dan 0:200 (b/b). Etanol $96 \%$ digunakan sebagai kontrol negatif dan antibiotik tetracycline $30 \mu \mathrm{g}$ sebagai kontrol positif. 
Ekstrak dengan beberapa perbandingan berbeda yang telah dipersiapkan sebelumnya selanjutnya dilakukan uji aktivitas antibakteri $E$. faecalis dan $E$. coli dengan metode kertas cakram (Mariani et al. 2020; Hidayat et al. 2019)). Sebanyak $20 \mu \mathrm{l}$ campuran ekstrak diteteskan pada kertas cakram yang berukuran $6 \mathrm{~mm}$. Setelah ekstrak terserap sempurna pada kertas cakram dan pelarut etanolnya telah kering maka dilanjutkan dengan meletakkan kertas tersebut pada cawan petri yang telah berisi media MHA dan bakteri E. faecalis ataupun E. coli (tingkat kekeruhan bakteri adalah $3 \times 10^{8} \mathrm{CFU} / \mathrm{ml}$ atau setara dengan $M c$. Farland 1). Proses inkubasi dilakukan selama satu hari (24 jam) pada suhu $35^{\circ} \mathrm{C}$, dan dilanjutkan dengan pengukuran zona bening (daerah penghambatan) yang berada disekitar kertas cakram. Data zona hambat yang dihasilkan selanjutnya dilakukan analisis statistik one-way anova menggunakan SPSS 22. Tingkat penghambatan yang dihasilkan dikategorikan menjadi: (1) diameter penghambatan $\geq 20 \mathrm{~mm}$ tergolong sangat kuat; (2) 11-19 mm tergolong kuat; (3) 5-10 $\mathrm{mm}$ tergolong sedang dan (4) $<5 \mathrm{~mm}$ dikategorikan lemah (Udawaty et al. 2019).

\section{HASIL DAN PEMBAHASAN}

Campuran dari ekstrak etanol kulit batang merkubung dan mangpurang dengan 5 level perbandingan diujikan pada dua jenis bakteri yaitu $E$. faecalis dan E. coli, selain itu pada kedua bakteri tersebut juga diberikan perlakuan kontrol positif yaitu tetracycline $(30 \mu \mathrm{g})$ dan etanol sebagai kontrol negatif. Hasil pengujian terhadap kedua jenis bakteri ini menunjukkan bahwa campuran dari ekstrak etanol kulit batang merkubung dan mangpurang memiliki aktivitas penghambatan terhadap pertumbuhan bakteri uji (Gambar 1). Zona hambat yang dihasilkan berkisar antara $0-$ 1,4 mm untuk bakteri E. faecalis dan 0 1,08 mm untuk bakteri E. coli (Gambar 2). Jika dibandingkan dengan kontrol positif yang menghasilkan zona hambat sebesar 12 dan $16 \mathrm{~mm}$, maka campuran ekstrak merkubung dan mangpurang memiliki aktivitas yang lebih rendah.

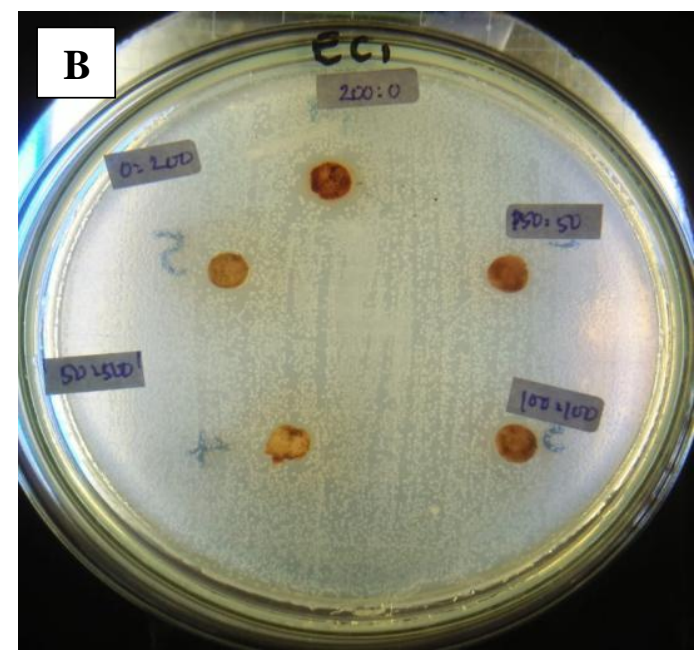

Gambar 1. Penghambatan pertumbuhan bakteri (A) E. faecalis dan (B) E. coli.

Berdasarkan hasil one-way anova terhadap perlakuan yang diberikan menunjukkan adanya pengaruh yang nyata terhadap diameter penghambatan pada kedua jenis bakteri uji. Pada pengujian terhadap bakteri E. faecalis, campuran ekstrak etanol kulit batang merkubung dan mangpurang menunjukkan hambatan pada penggunaan perbandingan (b/b) 200:0; 150:50; 100:100 dan 50:150, sedangkan pada perbandingan 0:200 tidak terjadi penghambatan. Jika dilihat dari trend yang 
terbentuk maka terjadi penurunan zona hambat dari perbandingan 200:0-0:200, dan penggunaan ekstrak secara tunggal untuk merkubung (200:0) menghasilkan zona hambat yang lebih besar dibandingkan yang lain, sebaliknya penggunaan ekstrak secara tunggal untuk mangpurang (0:200) tidak menunjukkan zona hambat. Hal ini berarti bahwa dalam penelitian ini ekstrak mangpurang tidak berkontribusi terhadap zona hambat yang terbentuk pada campuran ekstrak yang digunakan.

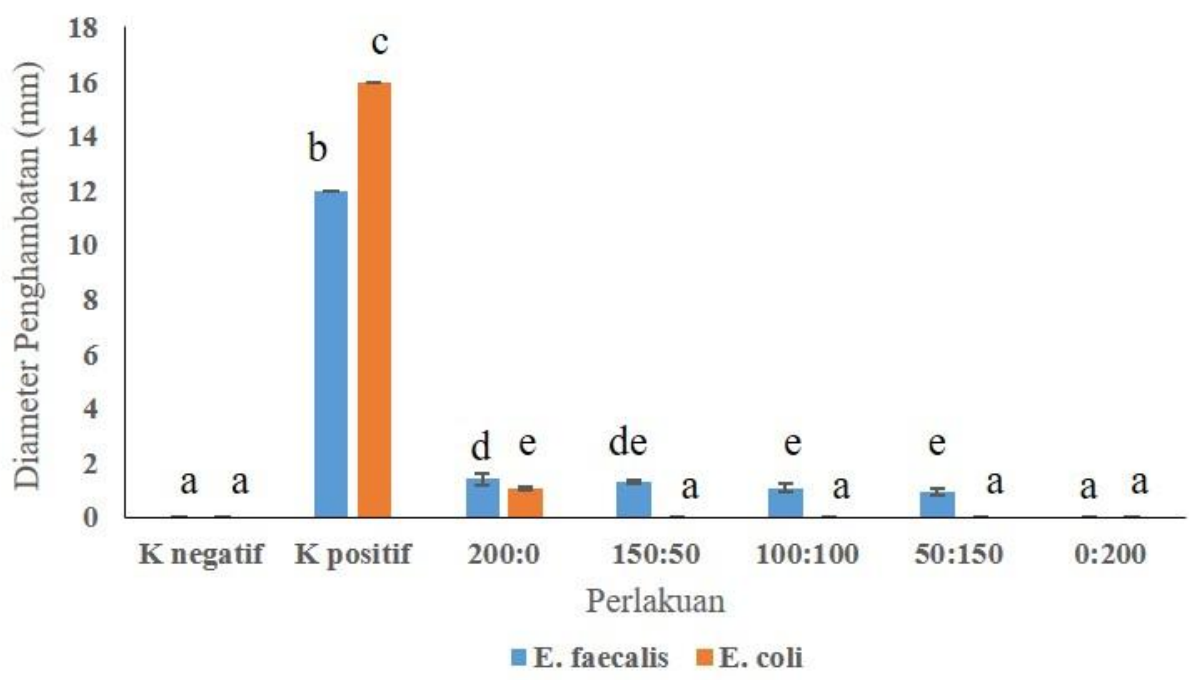

Gambar 2. Diameter penghambatan pertumbuhan bakteri E. faecalis dan E. coli. (Keterangan: nilai tengah perlakuan dengan huruf yang sama mengindikasikan tidak adanya perbedaan yang nyata pada level kepercayaan $95 \%$

Zona hambat yang dihasilkan dalam penelitian ini lebih rendah jika dikomparasikan dengan hasil penelitian Hidayat et al. (2019) terhadap bakteri $E$. faecalis yang menghasilkan zona hambat 5,25 mm untuk ekstrak merkubung dan 2,87 mm untuk mangpurang. Berdasarkan tingkat penghambatannya (zona hambat $\geq 20 \mathrm{~mm}$ tergolong sangat kuat; 11-19 mm kuat; 5-10 $\mathrm{mm}$ sedang dan $<5 \mathrm{~mm}$ lemah (Udawaty et al. 2019)), maka ekstrak merkubung tergolong dalam tingkat penghambatan yang lemah terhadap bakteri $E$. faecali

Pada bakteri E. coli, aktivitas penghambatan hanya terjadi pada perbandingan 200:0 atau hanya ekstrak tunggal dari merkubung, sedangkan campurannya tidak menunjukkan adanya respon hambatan. Hal ini berarti bahwa pencampuran ekstrak kulit batang tidak memberikan pengaruh terhadap aktivitas penghambatan $E$. coli. Jika dibandingkan dengan aktivitas penghambatan dari ekstrak daun merkubung terhadap E. coli (Apriani et al. 2014) maka aktivitas penghambatan dari ekstrak kulit kayu merkubung tergolong lebih rendah. Rendahnya penghambatan ini di duga karena ekstrak yang terdapat pada daun mengandung senyawa-senyawa bioaktif dengan konsentrasi yang lebih lebih tinggi dibandingkan dengan kulit kayu.

Bakteri E. coli tergolong kedalam bakteri Gram negatif dan dikenal mempunyai resistensi alami yang cukup tinggi. Hal ini dikarenakan E. coli dapat memproduksi enzim $\beta$-lactamase, dimana enzim tersebut berperan untuk menghambat kerja dari senyawa antibakteri (Allocati et al. 2013). Selain itu, bakteri E. coli yang juga memiliki struktur lapisan membran luar ganda yang terdiri atas lapisan fospolifid yang juga berperan dalam penghambatan terhadap senyawa antibakteri untuk masuk ke dalam tubuh bakteri (Nazzaro et al. 2013; Mariani et al. 2020).

Secara umum, campuran ekstrak mangpurang dan merkubung menunjukkan daya hambat yang rendah dikarenakan 
adanya efek antagonis dalam penghambatan bakteri oleh kandungan senyawa metabolit sekunder yang dimiliki oleh kedua jenis ekstrak tersebut. Hal serupa juga di laporkan oleh Qing-Hu et al. (2002) pada pengujian campuran ekstrak epigalokatekin galat yang merupakan penyusun utama dari tea catechin yang terdapat pada teh (Camillia sinensis) dan polymyxin $B$ yang diujikan ke bakteri $E$. coli. Kandungan senyawa metabolit yang dimiliki oleh epigalokatekin galat seperti tanin dan polifenol tidak menunjukkan sinergisitas dengan polymyxin B dalam menghambat pertumbuhan bakteri uji. Selanjutnya, Basri et al. (2014) dan Qin et al. (2013) menambahkan bahwa adanya aktivitas antagonis dalam penghambatan bakteri pada campuran dua atau lebih senyawa karena adanya pengurangan aktivitas dari metabolit sekunder yang dimiliki oleh salah satu senyawa campuran yang dikarenakan adanya penambahan senyawa lain yang digunakan dalam campuran.

Seperti yang dilaporkan oleh Hidayat et al. (2019), ekstrak merkubung memiliki senyawa alkaloid, flavonoid, saponin, terpenoid, tanin dan fenolik. Senyawasenyawa tersebut dilaporkan aktivitas antibakterinya oleh beberapa peneliti (Lelario et al 2018; Compean dan Ynalvez, 2014). Secara umum, senyawa metabolit sekunder yang berasal dari tumbuhan dapat memiliki aktivitas sebagai antibakteri karena mampu menghambat kerja enzim yang digunakan dalam metabolisme bakteri (Othman et al. 2019). Pada penggunaan konsentrasi yang rendah dari ekstrak antibakteri alami pada umumnya akan mengganggu pembentukan energi dari sel bakteri, tetapi apabila konsentrasi dinaikkan maka akan mampu membunuh bakteri karena adanya interupsi dari protein dinding sel dan penghambatan pembentukan komponen dinding sel (Lobritz et al. 2015; Mariani et al. 2020).

Kulit kayu merkubung dan mangpurang yang telah digunakan secara tradisional oleh masyarakat terbukti dapat menghambat pertumbuhan bakteri terutama bakteri $E$. faecalis dan E. coli walaupun dengan tingkat penghambatan yang lemah. Hasil penelitian ini menunjukkan bahwa penggunaan bahan alam dalam pengobatan tradisional dapat dilakukan secara tunggal maupun campuran.

\section{KESIMPULAN}

Campuran ekstrak etanol dari kulit batang merkubung dan mangpurang pada konsentrasi $200 \mathrm{mg} / \mathrm{ml}$ dengan perbandingan ekstrak 200:0; 150:50; 100;100 dan 50:150 (b/b) memiliki aktivitas penghambatan pertumbuhan bakteri E. faecalis dengan zona hambatan sebesar 1,4 mm; 1,3 mm; $1,09 \mathrm{~mm}$ dan $0,94 \mathrm{~mm}$. Penghambatan pertumbuhan bakteri $E$. coli hanya dapat dilakukan oleh ekstrak merkubung (200:0) dengan zona hambat $1,08 \mathrm{~mm}$. Perlu dilakukan penelitian lanjutan untuk mendapatkan konsentrasi hambat minimum (KHM) dan konsentrasi campuran terbaik dalam menghambat pertumbuhan bakteri $E$. faecalis dan E. coli.

\section{UCAPAN TERIMA KASIH}

Terima kasih kepada saudara Beri Hidayat yang telah memberikan ekstrak tanaman merkubung dan mengpurang.

\section{DAFTAR PUSTAKA}

Allocati N, Masulli M, Alexeyev MF, \& Di Ilio C (2013). Escherichia coli in Europe: An overview. Int. J. Environ. Res. Public Health. 10 (12): 6235-6254. http://dx.doi.org/10.3390/ijerph1012623 5.

Amirta R, Angi EM, Ramadhan R, Kusuma IW, Wiati CB, \& Haqiqi MT. (2017). Potensi Pemanfaatan Macaranga (Kiswanto, ed.). Samarinda, Kalimantan Timur: Mulawarman University Press. Apriani AS, Saleh C, \& Alimuddin (2014). Uji Fitokimia dan Aktivitas Antibakteri dari Tanaman Merkubung (Macaranga gigantea (Rchb.f. \& Zoll) Mull. Arg.) dengan Ekstrak Total, Fraksi nHeksana, Etil Asetat, dan Etanol Air Terhadap Bakteri Escherichia coli dan Staphylococcus aureus. Jurnal Kimia 
Mulawarman, 12(1), 37-41.

Basri DF, Xian LW, Abd. Shukor, \& Latif J (2014). Bacteriostatic Antimicrobial Combination Between Epsion-Viniferin and Vancomycin Against MethicilinResistant Staphylococcus aureus. BioMed Research International. 2014. 461756: $1-8$. https://dx.doi.org/10.1155/2014/461756.

Calsum U, Khumaidi A, \& Khaerati K (2018). Aktivitas Ekstrak Etanol Kulit Batang Kayu Jawa (Lannea coromandelica) terhadap Penyembuhan Luka Sayat pada Tikus Putih (Rattus Norvegicus L). Jurnal Farmasi Galenika, 4(2), 113-118. https://doi.org/10.22487/j24428744.201 8.v4.i2.11078.

Compean KL, \& Ynalves RA (2014). Antimicrobial Activity of Plant Secondary Metabolites: A Review. Research Journal of Medicinal Plant. 8 (5): 204-213.

https://doi.org/10.3923/rjmp.2014.204. 213.

Djuanda R, Helmika VA, Christabella F, Praata N, \& Sugiama V. K. (2019). Potensi Herbal Antibakteri Cuka Sari Apel terhadap Enterococcus faecalis sebagai Bahan Irigasi Saluran Akar. Sonde (Sound of Dentistry), 4(2), 24-40. Halim F, Warouw SM, Rampengan NH, \& Salendu P (2017). Hubungan Jumlah Koloni Escherichia coli dengan Derajat Dehidrasi pada Diare Akut. Sari Pediatri, 19(2), 81-85.

https://doi.org/10.14238/sp19.2.2017.8 $1-5$.

Hidayat B, Yusro F, \& Mariani Y (2019).

Kemampuan Ekstrak Kulit Kayu Dua Spesies Macaranga dalam Menghambat Pertumbuhan Enterococcus Faecalis. Jurnal Borneo Akcaya. 5(2), 95-109.

Lobritz MA, Belenky P, Porteb CB, Gutierrez A, Yang JH, Schwarz EG, Dwyerh DJ, Khalila AS, \& Collins JJ (2015). Antibiotic efficacy is linked to bacterial cellular respiration. PNAS. 112 (27): 8173-8180. http://dx.doi.org/ 10.1073/pnas.1509743112.
Lelario F, Scrano L, De Franchi S, Bonomo MG, Salzano G, Milan S, Milela L, \& Bufo SA (2018). Identification and Antimicrobial Activity of Most Representative Secondary Metabolites From Different Plant Species. Chemical and Biological Technologies in Agriculture. 5 (13): 1-12. https://doi.org/10.1186/s40538-0180125-0.

Mariani Y, Yusro F, \& Wardenaar E (2020). Aktivitas Ekstrak Metanol Daun Ulin (Eusideroxylon Zwageri Teijsm \& Binn) Terhadap Empat Jenis Bakteri Patogen. Jurnal Biologi Tropis, 20(1), 94.

https://doi.org/10.29303/jbt.v20i1.1642

Miksusanti, Elfita, \& Hotdelina S. (2012). Aktivitas Antioksidan dan Sifat Kestabilan Warna Campuran Ekstrak Etil Asetat Kulit Buah Manggis (Garcinia mangostana L.) dan Kayu Secang (Caesalpinia sappan L.). Jurnal Penelitian Sains, 15(2), 60-69.

Nazzaro F, Fratianni F, De Martino L, Cappola R, \& De Feo V (2013). Effect of Essential oils on pathogenic bacteria. Pharmaceuticals 6 (12): 1451-1474. http://dx.doi.org/10.3390/ph6121451.

Nuraini, Ilyas A, \& Novianty I (2015). Identifikasi dan Karakterisasi Senyawa Bioaktif Antikanker dari Ekstrak Etanol Kulit Batang Kayu Bitti (Vitex cofassus). Al Kimia, 3(2), 15-27.

Nuriana, Yusro F, \& Mariani Y. (2019). Sifat Antibakteri Enterococcus faecalis Ekstrak Metanol Kulit Kayu Mangga Pelam (Mangifera laurina Blum.). Jurnal Tengkawang, 9(2), 92-103. https://doi.org/10.26418/jt.v9i1.33635.

Othman L, Sleiman A, \& Abdel-Massih RM (2019). Antimicrobial Activity of Polyphenols and Alkaloids in Middle Eastern Plants. Frontiers in Microbiology. 10 (911): 1-28. https://doi.org/10.3399/fmicb.2019.009 11.

Pasaribu G, \& Setyawati T. (2011). Aktivitas Antioksidan dan Toksisitas Ekstrak Kulit Kayu Raru (Cotylelobium 
sp). Jurnal Penelitian Hasil Hutan, 29(4), 322-330.

Priandi F, Yusro F, Diba F, Mariani Y, \& Nurhaida. (2019). Uji Efektifitas Antibakteri Ekstrak Kulit batang Jambu Monyet (Bellucia pentamera Naudin) terhadap Pertumbuhan Bakteri Escherichia coli dan Salmonella typhi. Jurnal Tengkawang, 9(1), 27-37. https://doi.org/10.26418/jt.v9i1.33635.

Qing- Hu Z, Hua- Zhao W, Yoda Y, Asano

N, Hara Y, \& Shimamura T (2002).

Additive, Indifferent and Antagonistic Effects in Combination of Epigallocatechin Gallate with 12 non$\beta$-Lactam Antibiotics Against Methicilin-Resistant Staphylococcus aureus. Journal of Antimicrobial Chemotheraphy. 50: 1051-1054. https://doi.org/10.1092/jac/dkf250.

Qin R, Xiao K, Li B, Jiang W, Peng W, Zheng J, \& Zhou H (2013). The Combination of Catechin and Epicatechin Gallate From Fructus Crataegi Potentiates $\beta$ - Lactam Antibiotics Against MethichilinResistant Staphylococcus aureus (MRSA) in vitro and in vivo.
International Journal of Molecular Science. 2013 (14): 1802-1821. https://doi.org/10.3390/ijms14011802.

Udawaty W, Yusro F, \& Sisillia L (2019). Identifikasi Senyawa Kimia Minyak Sereh Wangi Klon G3 (Cymbopogon nardus L.) dengan Media Tanam Tanah Gambut dan Potensinya Sebagai Antibakteri Enterococcus faecalis. J. $\begin{array}{lll}\text { Tengkawang } \quad 9 & \text { (2): } 71-81 .\end{array}$ http://dx.doi.org/10.26418/jt.v9i2.

Wajdi S A, Kasmiyati S, \& Hastuti SP (2017). Uji Aktivitas Antibakteri Campuran Ekstrak Biji Kelor (Moringa oleifera) dan Daun Kersen (Muntingia calabura) terhadap Pseudomonas aeruginosa dan Bacillus subtilis. Journal of Tropical Biodiversity and Biotechnology, 2(1), 10-15. https://doi.org/10.22146/jtbb.13728.

Yusro F, Mariani Y, \& Wardenaar E (2019). Pemanfaatan Tumbuhan Obat untuk Mengatasi Gangguan Sistem Pencernaan oleh Suku Dayak Iban: Studi Kasus di Kabupaten Kapuas Hulu Kalimantan Barat. Jurnal Borneo Akcaya, 5(1), 58-72. 